\title{
PERSEPSI DAN PREFERENSI MASYARAKAT TERHADAP INFRASTRUKTUR HIJAU KOTA YOGYAKARTA
}

\author{
Community's Perceptions and \\ Preferences of Green \\ Infrastructure in Yogyakarta \\ City
}

\author{
Ririk Darti Pratiwi \\ Mahasiswa Program Studi Arsitektur \\ Lanskap, Sekolah Pascasarjana IPB \\ Email: ririk.26@gmail.com

\section{Indung Sitti Fatimah} \\ Staf Pengajar Departemen Arsitektur \\ Lanskap, Fakultas Pertanian IPB \\ Email: indungsittifatimah@gmail.com

\section{Aris Munandar} \\ Staf Pengajar Departemen Arsitektur \\ Lanskap, Fakultas Pertanian IPB \\ Email: amunandaripb@yahoo.com
}

\begin{abstract}
Green infrastructure has been indicated as promising measure for adaptation to climate change impact, especially in densely populated cities. Yogyakarta City was considered as a good representative for the case study, due its urban density and limited green spaces. Perceptual studies can generate more understanding of the research areas, and knowing the preferences for implementing green infrastructure can help urban planners identify more effective policy responses. The objective of this study are to analyze public perceptions and preferences on climate change and mitigation through green infrastructure, and to provide recomendation of green infrastructure development in Yogyakarta City. The study area located in Yogyakarta City that divided into three Zones based on the difference proportion of surface temperature by previous research. Data collecting for public perceptions and preferences were conducted by online questionnaires. Chi-Square analysis and descriptive statistics were used to analyze public perceptions and preferences data. The results showed that the differences between 3 Zones of study areas influenced differences in public perceptions, but not significantly affect preferences for green infrastructure. Recommendations on green infrastructure development that effective to improve micro climate based on public preferences will be done by developing urban green streets and zoo or urban forest by prioritizing ecological function, while at the micro scale priority will be done by developing neighborhood parks and home garden according to the results of each zone's preferences. Awareness of this environmental problems can serve as a tool for adapting and mitigating cities to climate change to improve urban planning strategies.
\end{abstract}

Keywords: climate change, green infrastructure, perception, preference

\section{PENDAHULUAN}

Dampak perubahan iklim bagi kota semakin mendapat perhatian. Hal ini menunjukan bahwa kombinasi dari permasalahan peningkatan populasi dan kepadatan pembangunan di kota tidak mewakili kondisi ideal untuk mengatasi perubahan iklim. Perubahan iklim dengan cuaca ekstrim dapat menyebabkan peningkatan banjir, kekeringan dan gelombang panas yang tidak hanya menyebabkan kerusakan finansial namun juga menjadi ancaman terhadap kesehatan dan keselamatan masyarakat (Gao et al. 2015). Pertumbuhan perkotaan yang mengubah kota dan pedesaan di sekitarnya memberikan banyak tantangan untuk pemeliharaan ruang terbuka hijau (RTH), kesehatan, serta kesejahteraan manusia (Tzoulas et al. 2007).

Infrastruktur hijau diyakini memiliki potensi yang cukup besar untuk menyesuaikan perubahan kota dengan beberapa dampak perubahan iklim yang muncul seperti dampak urban heat island (UHI), peningkatan banjir, kecepatan angin, dan curah hujan yang lebih episodik, terutama di kota berpenduduk padat di mana jarang ditemuinya ruang hijau dengan berskala besar (Brown et.al. 2015, Demuzere et al. 2014). Menurut Countryside Agency (2006), infrastruktur hijau terdiri atas jaringan terencana ruang hijau multifungsi yang berkontribusi untuk melindungi habitat alami dan keanekaragaman hayati, dapat menanggapi perubahan iklim, mengaktifkan gaya hidup berkelanjutan, meningkatkan kesejahteraan kehidupan perkotaan, meningkatkan aksesibilitas dari aset utama rekreasi dan ruang hijau, dan membantu memperbaiki perencanaan dan pengelolaan jangka panjang dari ruang hijau.
Kota Yogyakarta merupakan studi kasus yang representatif karena merupakan kota dengan kepadatan tinggi yang berkembang pesat dengan ruang hijau terbatas di kawasan perkotaan. Berlangsungnya pembangunan Kota Yogyakarta yang berada di tengah-tengah Provinsi Daerah Istimewa Yogyakarta memiliki potensi terjadinya dampak negatif seperti fenomena UHI. UHI dianalogikan sebagai "pulau" yang memiliki suhu permukaan udara panas terpusat pada area urban dan akan semakin turun suhunya pada daerah suburban/rural di sekitarnya (Guntara 2015).

Untuk mendapatkan kepercayaan masyarakat mengenai manfaat infrastruktur hijau, penting untuk memahami bagaimana pendapat masyarakat tentang masalah yang berhubungan dengan infrastruktur hijau (Derkzen et al. 2017). Namun kesulitannya terdapat pada keterbatasan informasi mengenai hal-hal seperti, pendapat dan kekhawatiran masyarakat tentang dampak perubahan iklim (kebutuhan untuk beradaptasi), sejauh mana masyarakat mengakui manfaat infrastruktur hijau untuk meringankan dampak tersebut, dan mengenai preferensi masyarakat terhadap implementasi infrastruktur hijau, termasuk kesediaan mereka untuk membayar (willingness to pay) (Byrne \& Yang 2015, Madureira \& Andresen 2015). Studi persepsi dapat menghasilkan lebih banyak pemahaman mengenai kawasan penelitian yang sedang dikembangkan dibandingkan dengan penelitian kuantitatif (Chan et al. 2012), sedangkan memahami preferensi untuk implementasi infrastruktur hijau dapat membantu perencana kota untuk mengidentifikasi respon terhadap kebijakan dengan lebih efektif (Derkzen et al. 2017). 
Keberhasilan penerapan infrastruktur hijau di banyak kota dan negara lain tidak terlepas dari dukungan yang besar dari masyarakat. Oleh karena itu, penelitian ini bertujuan untuk menganalisis persepsi dan peferensi masyarakat mengenai perubahan iklim dan mitigasinya melalui infrastruktur hijau, dan menyusun konsep rekomendasi pengembangan infrastruktur hijau di Kota Yogyakarta. Dengan demikian, penelitian ini diharapkan dapat menjadi bahan masukan bagi pemangku kepentingan (stakeholder) dalam perencanaan infrastruktur hijau kota dalam upaya memitigasi dampak perubahan iklim, dan meningkatkan kualitas infrastruktur hijau Kota Yogyakarta berdasarkan keinginan dari masyarakatnya.

\section{METODE PENELITIAN}

\section{Lokasi dan Waktu Penelitian}

Penelitian ini dilaksanakan di Kota Yogyakarta, Provinsi Daerah Istimewa Yogyakarta dengan luas wilayah sebesar $32.5 \mathrm{~km}^{2}$. Secara geografis, Kota Yogyakarta terletak antara $110^{\circ} 24^{\prime} 19^{\prime \prime}-110^{\circ} 28^{\prime} 53^{\prime \prime}$ BT dan 07 $15^{\prime} 24^{\prime \prime}-07^{\circ} 49^{\prime} 26^{\prime \prime}$ LS. Secara administratif Kota Yogyakarta terdiri dari 14 kecamatan dan 45 kelurahan. Pembagian zona lokasi penelitian ini berdasarkan hasil dari penelitian sebelumnya oleh Pratiwi (2019). Tabel 1 menjelaskan tentang persentase luas area prioritas tinggi pada masing-

\section{Alat dan Bahan}

Peralatan yang akan digunakan pada penelitian ini, meliputi kamera digital, seperangkat laptop, serta berbagai software seperti Microsoft Word 2016, Microsoft Excel 2016, Adobe Photoshop CC 2015, IBM SPSS Statistics 24.0, dan kuisioner online dengan format google form. Selain itu, data pendukung dari berbagai sumber dan laporan terdahulu juga menjadi referensi dan pertimbangan dalam melakukan penelitian ini.

\section{Metode Analisis Data}

Pengambilan data penelitian melalui penyebaran kuisioner yang dilakukan pada bulan Desember 2017 yang dilakukan secara online dalam format formulir google form dan disebarkan melalui media sosial (Facebook, Instagram, Twitter, WhatsApp), kemudian kuisioner diisi secara mandiri oleh responden (self administered questionnaire). Pemilihan sampel untuk responden dilakukan secara purposive sampling. Populasi yang mewakili dalam penelitian ini adalah masyarakat yang berdomisili di Kota Yogyakarta, kriteria sampel responden pada penelitian ini adalah masyarakat asli maupun masyarakat pendatang yang minimal telah lama menetap di Kota Yogyakarta selama 1 hingga 2 tahun karena dianggap sudah cukup paham dengan kondisi wilayah

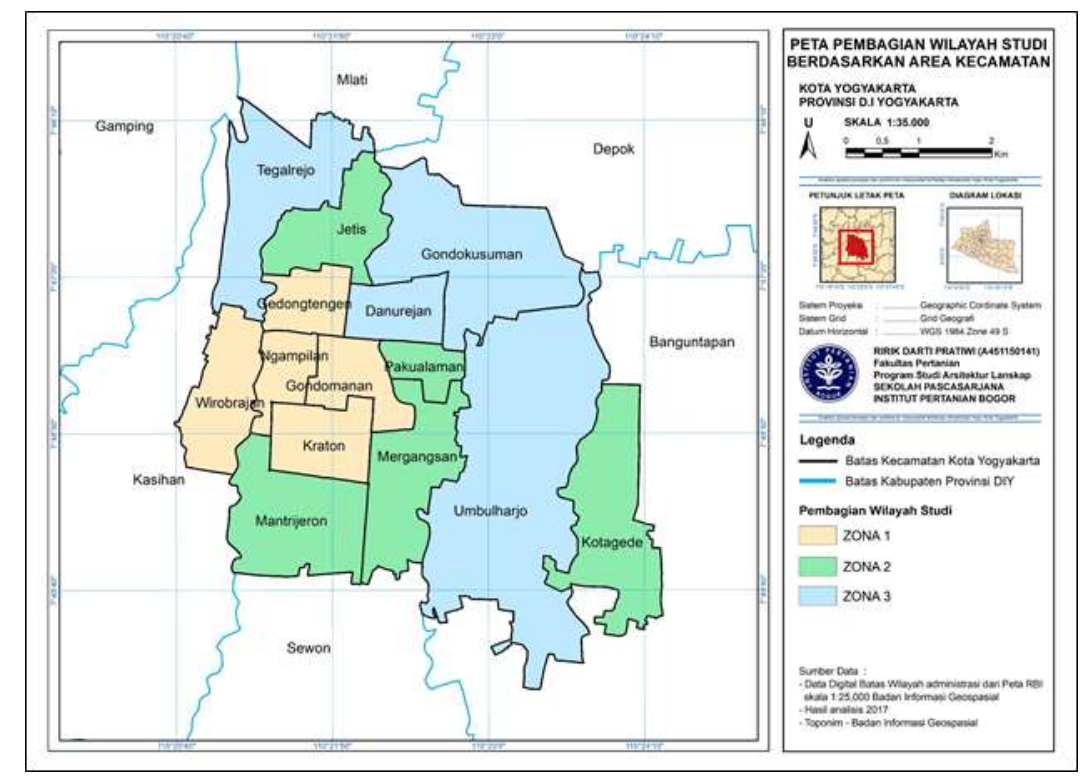

Gambar 1. Lokasi Penelitian Pembagian Zona Wilayah Studi

masing kecamatan dan kemudian akan dibagi lagi menjadi 3 kelompok area prioritas: Zona 1 (prioritas tinggi) terdiri atas: Kecamatan Kraton, Ngampilan, Wirobrajan Gedongtengen, dan Gondomanan, dengan luas area prioritas sebesar $4.03 \mathrm{~km}^{2}$. Zona 2 (prioritas sedang) Zona 2 terdiri atas: Kecamatan Pakualaman, Jetis, Mantrijeron, Kotagede, dan Mergangsan, dengan luas area prioritas sebesar $4.47 \mathrm{~km}^{2}$. Zona 3 (prioritas rendah) terdiri atas: Kecamatan Tegalrejo, Danurejan, Gondokusuman, dan Umbulharjo, dengan luas area prioritas sebesar 5.13 $\mathrm{km}^{2}$. Pembagian zona studi dapat dilihat melalui Gambar 1, dengan Zona 1 diwakili oleh warna merah muda, Zona 2 diwakili oleh warna hijau, dan Zona 3 diwakili warna biru. Penelitian persepsi dan preferensi ini sendiri dilakukan selama tujuh (7) bulan, yaitu dimulai dari bulan Agustus 2017 hingga bulan Februari 2018.
Kota Yogyakarta. Statistik deskriptif digunakan untuk menganalisis data deskriptif, kemudian metode yang digunakan untuk menganalisis persepsi dan preferensi masyarakat adalah metode uji analisis Chi-Square. Pada penelitian ini, uji analisis Chi-Square digunakan untuk mengetahui perbedaan proporsi hasil jawaban responden antara ketiga zona studi. Analisis dilakukan dengan menggunakan program SPSS 24.0.

Kuesioner disusun menjadi dua bagian dengan ditambah pertanyaan mengenai informasi sosio-demografis responden (jenis kelamin, umur, domisili, pendidikan, pekerjaan, dan asal daerah). Materi kuisioner yang diajukan mengenai tanggapan responden terhadap perubahan iklim dan pengetahuan mereka terkait infrastruktur hijau. Mereka diminta untuk menilai jenis infrastruktur hijau yang dianggap paling banyak memberikan jasa ekosistem dengan menggunakan foto- 
foto tipikal infrastruktur hijau perkotaan. Foto diambil pada bulan Agustus 2017 di wilayah studi. Kemudian, responden diberikan pertanyaan mengenai manfaat yang dianggap paling penting yang diberikan oleh infrastruktur hijau, dan pertanyaan mengenai tingkat kualitas dan kuantitas infrastruktur hijau yang ada di lingkungan responden.
Menurut hasil persentase yang disajikan pada Tabel 2, rata-rata sebanyak $81 \%$ responden dari 90 orang setuju bahwa perubahan iklim merupakan permasalahan bagi kota, dan mereka khawatir akan permasalahan tersebut. Sebagian responden mengungkapkan pendapat mereka tentang bagaimana cara memitigasi perubahan iklim, yaitu dengan melakukan penghijauan dan memperbanyak

Tabel 1. Pembagian Kelompok Wilayah Berdasarkan Persentase Luas Wilayah Prioritas Tinggi dari Total Luas Wilayah Kecamatan

\begin{tabular}{clccc}
\hline $\begin{array}{c}\text { Kelompok area } \\
\text { prioritas }\end{array}$ & \multicolumn{1}{c}{ Kecamatan } & $\begin{array}{c}\text { Luas Wilayah } \\
\left(\mathrm{km}^{2}\right)\end{array}$ & $\begin{array}{c}\text { Luas wilayah dengan } \\
\text { prioritas tinggi }\left(\mathrm{km}^{2}\right)\end{array}$ & $\begin{array}{c}\text { Persentase wilayah } \\
\text { dengan area prioritas } \\
\text { tinggi (\%) }\end{array}$ \\
\hline Zona 1 & Kraton & 1.38 & 1.03 & 74.28 \\
& Ngampilan & 0.84 & 0.58 & 68.85 \\
& Wirobrajan & 1.76 & 1.12 & 63.72 \\
& Gedongtengen & 0.98 & 0.60 & 61.30 \\
& Gondomanan & 1.15 & 0.70 & 60.75 \\
& Pakualaman & 0.64 & 0.33 & 51.01 \\
& Jetis & 1.72 & 0.77 & 44.90 \\
& Mantrijeron & 2.71 & 1.17 & 43.26 \\
& Kotagede & 2.99 & 1.24 & 41.56 \\
& Mergangsan & 2.35 & 0.96 & 40.98 \\
& Tegalrejo & 2.97 & 1.09 & 36.85 \\
& Danurejan & 1.10 & 0.39 & 35.58 \\
& Gondokusuman & 4.13 & 1.35 & 32.67 \\
& Umbulharjo & 8.26 & 2.30 & 27.84 \\
\hline
\end{tabular}

Materi selanjutnya adalah menentukan preferensi untuk implementasi infrastruktur hijau dalam skala kota dan skala lingkungan. Responden diberi pertanyaan mengenai preferensi dari manfaat infrastruktur hijau yang ingin diprioritaskan, jenis vegetasi yang diinginkan pada beberapa jenis infrastruktur hijau kota, dan pertanyaan mengenai preferensi jenis perencanaan dan pengelolaan infrastruktur hijau yang diusulkan.

Hasil penelitian dapat digunakan sebagai bahan rekomendasi untuk mengembangkan infrastruktur hijau yang dapat berkontribusi dalam memperbaiki iklim mikro kota, dan sesuai dengan keinginan masyarakat agar perencanaan kota dapat diterima masyarakat secara tepat sasaran.

\section{HASIL DAN PEMBAHASAN}

Analisis mengenai persepsi dan preferensi masyarakat dilakukan untuk melihat sejauh mana pemahaman masyarakat mengenai infrastruktur hijau Kota Yogyakarta saat ini pada masing-masing area prioritas, dan apa yang masyarakat inginkan untuk pengembangan infrastruktur hijau. Jumlah total responden pada penelitian ini sebanyak 90 orang. Mayoritas jenis kelamin responden adalah wanita. Usia mayoritas responden berusia 16-25 tahun. Tingkat pendidikan formal responden mayoritas adalah Sarjana (S1/ S2/ S3). Jenis pekerjaan responden mayoritas adalah pelajar atau mahasiswa. Tempat menetap mayoritas responden adalah Kecamatan Wirobrajan. Asal daerah mayoritas responden adalah masyarakat asli Kota Yogyakarta (Gambar 2).

\section{Persepsi Mengenai Infrastruktur Hijau}

Perubahan Iklim Merupakan Permasalahan Kota
$\mathrm{RTH}$, sisanya menjawab dengan mengurangi volume kendaraan bermotor, mengurangi pembangunan, dan mengurangi penggunaan energi. Mayoritas responden telah memiliki kesadaran mengenai isu terkait perubahan iklim dan paham bagaimana cara memitigasi masalah tersebut. Prilaku dalam mendukung tindakan mitigasi terhadap perubahan iklim dengan sukarela oleh individu bergantung pada kesadaran dan kekhawatiran masyarakat tentang isu tersebut, kesediaan untuk bertindak, dan kesanggupan untuk berubah. Memitigasi perubahan iklim global tidak hanya membutuhkan tindakan dari pemerintah tetapi juga kerja sama dari masyarakat (Semenza et al. 2008).

\section{Pengetahuan Mengenai Instrastruktur Hijau}

Tabel 2 menunjukkan terdapat perbedaan yang signifikan antara 3 zona terkait pengetahuan responden mengenai infrastruktur hijau ( $\mathrm{p}<0.05)$. Mayoritas responden pada Zona 1 menyatakan bahwa mereka mengetahui apa yang dimaksud dengan infrastruktur hijau (80\%), sedangkan hanya $53.3 \%$ responden pada Zona 2 dan 3 yang menyatakan demikian. Namun, rata-rata dari ketiga zona hanya $50 \%$ responden yang menyatakan bahwa mereka mengetahui elemen apa saja yang termasuk ke dalam infrastruktur hijau dan dapat menyebutkan salah satu contonya dengan tepat. Mayoritas responden menyebutkan RTH, taman kota, dan hutan kota merupakan contoh elemen dari infrastruktur hijau. Hal tersebut menunjukkan bahwa, sebagian responden telah mengetahui istilah infrastruktur hijau meskipun jumlahnya belum signifikan. Menurut Nurisjah (2005), program penyuluhan melalui kegiatan pemasyarakatan infrastruktur hijau perlu dilakukan untuk meningkatkan pengetahuan masyarakat mengenai kepentingan dan makna infrastruktur hijau terhadap perbaikan kualitas 
lingkungan kota dan terhadap tingkat kesejahteraan dan kesehatannya.

Terkait kondisi kualitas infrastruktur hijau pada lingkungan responden di Zona 1, hanya sebesar 23.3\% responden yang menyatakan kualitas infrastruktur hijau pada lingkungannya sudah baik, $30 \%$ pada Zona 2, dan $33.3 \%$ pada Zona 3. Kemudian, hanya sebanyak $13.3 \%$ responden di Zona 1 menyatakan bahwa kuantitas infrastruktur hijau di lingkungan kecamatannya sudah cukup, sebanyak $26.7 \%$ pada Zona 2 , dan $23.3 \%$ di Zona 3 . Hal ini sejalan dengan kondisi umum infrastruktur hijau yang telah diidentifikasi pada masing-masing zona, bahwa Zona 1 merupakan area padat penduduk, dan infrastruktur hijau masih kurang dibandingkan dengan Zona 2 dan 3.

Jenis Kelamin

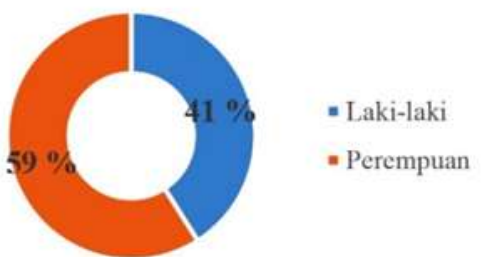

Pendidikan

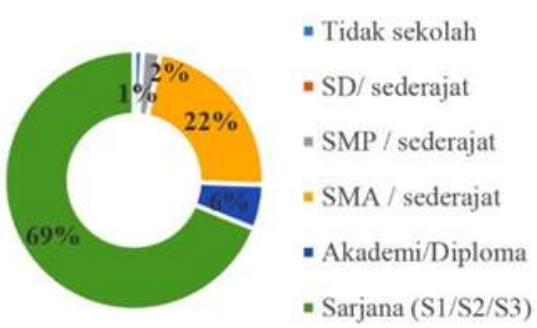

Tempat menetap

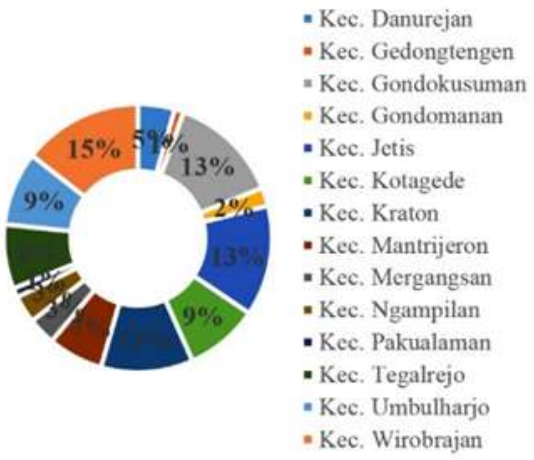

pada jenis infrastruktur hijau hutan kota taukebun binatang $(\mathrm{p}<0.05)$. Nilai yang cukup tinggi diberikan responden di Zona 1 pada pilihan hutan kota atau kebun binatang. Hal tersebut diduga karena tidak terdapatnya jenis infrastruktur hijau berupa hutan kota atau kebun binatang pada area tersebut, sedangkan Kebun Binatang Gembira Loka terletak pada area perbatasan antara Zona 2 dan dan 3. Nilai rendah yang diperoleh vertical garden diduga karena masyarakat masih relatif kurang familiar dan terdapat kekhawatiran mengenai pemeliharaannya seperti yang terjadi pada penelitian Derkzen et al. (2017). Jenis infrastruktur hijau berupa RTB seperti embung dan sungai menurut responden juga masih dianggap kurang memberikan banyak manfaat. Kondisi umum RTB yang ada di Kota Yogyakarta seperti sempadan sungai

Usia

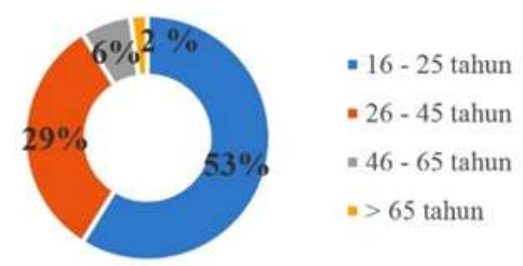

Pekerjaan

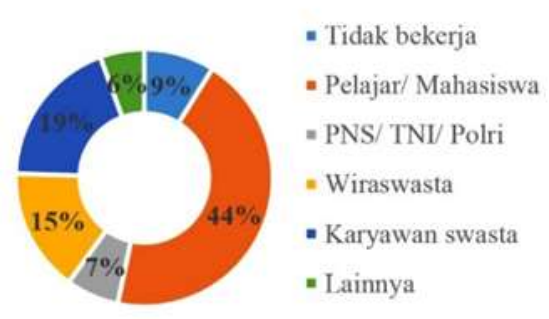

Asal daerah

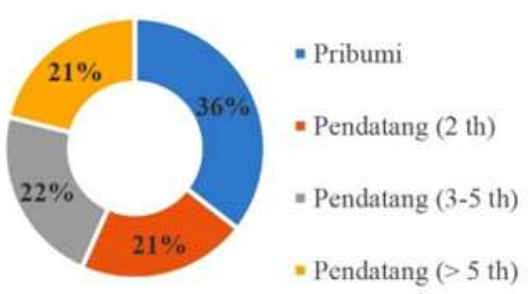

Gambar 2. Karakteristik Responden (1) Jenis Kelamin, (2) Usia, (3) Pendidikan, (4) Pekerjaan, (5) Tempat Menetap, (6) Asal Daerah

\section{Jenis Insfrastruktur Hijau yang Dimiliki Memberikan Banyak Manfaat}

Pada Zona 1, 2 dan 3 jenis infrastruktur hijau yang dinilai paling banyak memberikan manfaat adalah jalur hijau kota, sedangkan yang dinilai paling sedikit memberikan manfaat di Zona 1 dan Zona 3 adalah green roof/ vertical garden, kemudian rumput atau alun-alun pada Zona 2. Hasil analisis Chi-Square menunjukkan, terdapat perbedaan proporsi yang signifikan antara Zona 1 dan 2 mayoritas telah diokupasi menjadi permukiman padat, sehingga masyarakat cenderung memanfaatkan sungai sebagai tempat pembuangan akhir limbah rumah tangga. Padahal RTB juga dapat memberikan banyak manfaat dalam memitigasi permasalahan perubahan iklim. Ekosistem akuatik perkotaan sangat penting karena dapat mendukung kesehatan dan kesejahteraan manusia dengan manfaatnya dalam regulasi siklus air, mengurangi air limpasan perkotaan, dan memberikan manfaat rekreasi (Kati dan Jari 2016). 


\section{Manfaat Insfrastruktur Hijau yang Dianggap Paling Penting}

Berdasarkan hasil analisis yang disajikan pada Tabel 2, pada Zona 1 dan 3 manfaat untuk meningkatkan kualitas udara atau mengurangi polusi dinilai paling penting, sedangkan manfaat sebagai sarana rekreasi dianggap sebagai manfaat paling rendah pada Zona 1, 2 dan 3 . Hasil analisis Chi-Square menunjukan terdapat perbedaan proporsi yang signifikan antara Zona 2 dan 3 pada persepsi pemilihan manfaat dalam meningkatkan kualitas udara atau mengurangi polusi $(\mathrm{p}<0.05)$. Hal tersebut dikarenakan responden pada Zona 2 selain memiliki perhatian pada manfaat meningkatkan kualitas udara atau mengurangi polusi, menganggap manfaat pengaturan iklim mikro lebih penting, sehingga persentase yang diperoleh hampir setara, sedangkan pada Zona 3 mayoritas responden menilai meningkatkan kualitas udara merupakan manfaat yang paling penting. Hasil persentase tersebut menunjukkan bahwa masyarakat menganggap udara yang bersih dan berkualitas lebih penting bagi kota dan mereka khawatir dengan dampak pemanasan global, seperti yang terjadi pada penelitian Derkzen et al. (2017). perhatian dari responden di Zona 1. Pada Zona 2, membantu melalui pembayaran pajak dan membentuk komunitas hijau serta aktif dalam masyarakat memiliki peringkat yang setara pada urutan akhir. Pada Zona 3 membantu melalui pembayaran pajak berada pada peringkat terakhir. Hasil analisis Chi-Square menunjukan terdapat perbedaan yang signifikan dari pilihan responden pada Zona 1 dan 2 dalam pemilihan kontribusi membantu pemeliharaan dalam skala rumah $(p<0.05)$. Hal tersebut dikarenakan hasil persentase pilihan responden pada Zona 2 lebih merata dibanding Zona 1 dan 3 yang mayoritas respondennya memilih jenis kontribusi membantu pemeliharaan dalam skala rumah. Jenis kontribusi tersebut banyak dipilih diduga karena hal tersebut dianggap sebagai kontribusi yang paling mudah dilakukan dan dapat dimulai dengan melakukan tindakan dari lingkungan mikro responden. Masyarakat dapat memperoleh banyak manfaat dari pemeliharaan tanaman di pekarangan mereka. Menurut Barau (2015) Semua bentuk proyek infrastruktur hijau dapat dipertimbangkan karena memiliki manfaat potensial bagi masyarakat dan lingkungan setempat.

Tabel 2. Persentase dan Hasil Uji Chi-Square Persepsi Responden

\begin{tabular}{|c|c|c|c|c|c|}
\hline \multirow{2}{*}{ No } & \multirow{2}{*}{ Materi kuisioner } & \multicolumn{3}{|c|}{ Persentase $(\%)$} & \multirow{2}{*}{$\begin{array}{l}\text { Chi- } \\
\text { Square }\end{array}$} \\
\hline & & Zona 1 & Zona 2 & Zona 3 & \\
\hline 1 & Perubahan iklim merupakan permasalahan kota & 80.0 & 80.0 & 83.3 & 1.000 \\
\hline \multirow[t]{5}{*}{2} & Pengetahuan mengenai infrastruktur hijau & & & & \\
\hline & Pengertian & 80.0 & 53.3 & 53.3 & $0.049^{*}$ \\
\hline & Contoh & 66.7 & 40.0 & 46.7 & 0.099 \\
\hline & Kualitas & 23.3 & 30.0 & 33.3 & 0.685 \\
\hline & Kuantitas & 13.3 & 26.7 & 23.3 & 0.420 \\
\hline \multirow[t]{9}{*}{3} & $\begin{array}{l}\text { Infrastruktur hijau yang memberikan banyak } \\
\text { manfaat }\end{array}$ & & & & \\
\hline & Taman kota & 66.7 & 56.7 & 56.7 & 0.659 \\
\hline & Green roof/vertical garden & 23.3 & 20.0 & 20.0 & 0.935 \\
\hline & Hutan kota/ kebun binatang & 80.0 & 40.0 & 66.7 & $0.005^{*}$ \\
\hline & Danau/ embung & 36.7 & 30.0 & 50.0 & 0.270 \\
\hline & Jalur hijau kota & 93.3 & 96.7 & 80.0 & 0.075 \\
\hline & Lapangan rumput/ alun-alun & 26.7 & 13.3 & 23.3 & 0.420 \\
\hline & Sungai & 36.7 & 26.7 & 33.3 & 0.700 \\
\hline & Taman lingkungan & 40.0 & 43.3 & 46.7 & 0.873 \\
\hline \multirow[t]{6}{*}{4} & Manfaat infrastruktur hijau & & & & \\
\hline & Pengaturan iklim mikro & 33.3 & 36.7 & 16.7 & 0.127 \\
\hline & Pengendalian air limpasan/ mengurangi banjir & 13.3 & 20.0 & 16.7 & 0.787 \\
\hline & Meningkatkan kualitas udara/ mengurangi polusi & 50.0 & 30.0 & 66.7 & $0.017^{*}$ \\
\hline & Sarana rekreasi & 3.3 & 13.3 & 0 & 0.657 \\
\hline & Total & 100.0 & 100.0 & 100.0 & \\
\hline \multirow[t]{7}{*}{5} & Kontribusi & & & & \\
\hline & Membantu pemeliharaan dalam skala rumah & 83.3 & 50.0 & 70.0 & $0.021^{*}$ \\
\hline & Membantu melalui pembayaran pajak & 3.3 & 13.3 & 0 & 0.092 \\
\hline & Menaati peraturan pemerintah & 0 & 20.0 & 16.7 & 1.000 \\
\hline & Membentuk komunitas hijau, aktif di masyarakat & 13.3 & 13.3 & 10.0 & 1.000 \\
\hline & Lainnya & 0 & 3.3 & 3.3 & 1.000 \\
\hline & Total & 100.0 & 100.0 & 100.0 & \\
\hline
\end{tabular}

Keterangan: * menunjukkan perbedaan bersifat signifikan (nilai uji a < 0.05)

Kontribusi Masyarakat dalam Mendukung Implementasi Insfrastruktur Hijau

Jenis kontribusi paling banyak dipilih pada Zona 1, 2, dan 3 adalah, membantu pemeliharaan dalam skala rumah. Menaati peraturan pemerintah tidak mendapatkan
Ditemukan bahwa tingkat willingness to pay (WTP) dengan membantu pemerintah melalui pembayaran pajak pada area prioritas rendah mencapai $0 \%$, hal ini kemungkinan dipengaruhi oleh faktor tingkat pendidikan mayoritas pada area ini adalah SMA atau sederajat. Pada area ini juga 
Tabel 3. Persentase Hasil Preferensi Responden

\begin{tabular}{|c|c|c|c|c|c|}
\hline \multirow{2}{*}{ No } & \multirow{2}{*}{$\begin{array}{l}\text { Materi kuisioner mengenai } \\
\text { preferensi }\end{array}$} & \multicolumn{3}{|c|}{ Persentase $(\%)$} & \multirow{2}{*}{$\begin{array}{l}\text { Chi- } \\
\text { Square }\end{array}$} \\
\hline & & Zona 1 & Zona 2 & Zona 3 & \\
\hline \multirow[t]{6}{*}{1} & Manfaat infrastruktur hijau & & & & \\
\hline & Bermanfaat secara ekologis & 50.0 & 53.3 & 60.0 & 0.731 \\
\hline & Keindahan lebih utama & 10.0 & 10.0 & 3.3 & 0.690 \\
\hline & Berproduksi dapat dipanen & 6.7 & 6.7 & 13.3 & 0.578 \\
\hline & Kenyamanan lebih utama & 33.3 & 30.0 & 23.3 & 0.621 \\
\hline & Total & 100.0 & 100 & 100.0 & \\
\hline \multirow[t]{8}{*}{2} & Skala kota & & & & \\
\hline & Taman Kota & 6.7 & 10.0 & 3.3 & 0.994 \\
\hline & Hutan Kota/ Kebun Binatang & 16.7 & 6.7 & 36.7 & $0.050^{*}$ \\
\hline & Danau/ Embung & 3.3 & 3.3 & 10.0 & 0.846 \\
\hline & Jalur hijau jalan & 63.3 & 63.3 & 30.0 & $0.012^{*}$ \\
\hline & Lapangan/ alun-alun & 6.7 & 6.7 & 3.3 & 1.000 \\
\hline & Sungai dan sempadannya & 3.3 & 10.0 & 16.7 & 0.707 \\
\hline & Total & 100.0 & 100.0 & 100.0 & \\
\hline \multirow[t]{6}{*}{3} & Skala lingkungan & & & & \\
\hline & Green roof & 10.0 & 10.0 & 13.3 & 0.894 \\
\hline & Pekarangan & 40.0 & 30.0 & 36.7 & $0.012^{*}$ \\
\hline & Taman lingkungan & 46.7 & 46.7 & 36.7 & 0.196 \\
\hline & Green wall & 3.3 & 13.3 & 13.3 & 0.216 \\
\hline & Total & 100.0 & 100.0 & 100.0 & \\
\hline \multirow[t]{6}{*}{4} & Skala prioritas & & & & \\
\hline & Rumah & 16.7 & 26.7 & 13.3 & 0.390 \\
\hline & Lingkungan & 33.3 & 36.7 & 43.3 & 0.718 \\
\hline & Kecamatan & 26.7 & 13.3 & 23.3 & 0.420 \\
\hline & Kota & 23.3 & 23.3 & 20.0 & 1.000 \\
\hline & Total & 100.0 & 100.0 & 100.0 & \\
\hline \multirow[t]{6}{*}{5} & Vegetasi jalur hijau kota & & & & \\
\hline & Rumput & 0 & 3.3 & 3.3 & 0.974 \\
\hline & Pohon peneduh & 96.7 & 93.3 & 83.3 & 0.444 \\
\hline & Tanaman berbunga & 3.3 & 3.3 & 13.3 & 0.473 \\
\hline & Semak & 0 & 0 & 0 & - \\
\hline & Total & 100.0 & 100.0 & 100.0 & \\
\hline \multirow[t]{6}{*}{6} & Vegetasi taman kota & & & & \\
\hline & Rumput & 10.0 & 3.3 & 6.7 & 0.994 \\
\hline & Pohon peneduh & 56.7 & 80.0 & 60.0 & 0.121 \\
\hline & Tanaman berbunga & 33.3 & 16.7 & 33.3 & 0.250 \\
\hline & Semak & 0 & 0 & 0 & - \\
\hline & Total & 100.0 & 100.0 & 100.0 & \\
\hline \multirow[t]{6}{*}{7} & $\begin{array}{l}\text { Perencanaan dan pengelolaan } \\
\text { yang diusulkan }\end{array}$ & & & & \\
\hline & Membuat kebijakan tegas & 20.0 & 13.3 & 6.7 & 0.836 \\
\hline & $\begin{array}{l}\text { Membebaskan kawasan yang } \\
\text { memiliki peruntukan sebagai } \\
\text { infrastruktur hijau }\end{array}$ & 40.0 & 26.7 & 36.7 & 1.000 \\
\hline & Mengoptimalkan yang ada & 6.7 & 26.7 & 20.0 & $0.019 *$ \\
\hline & $\begin{array}{l}\text { Mengembangkan berdasarkan } \\
\text { area prioritas }\end{array}$ & 33.3 & 33.3 & 36.7 & 0.393 \\
\hline & Total & 100.0 & 100.0 & 100.0 & \\
\hline
\end{tabular}

Keterangan: * menunjukkan perbedaan bersifat signifikan (nilai uji a < 0.05)

tingkat pekerjaan responden yang tidak bekerja dan sebagai pelajar/ mahasiswa paling banyak diantara ketiga zona, sehingga kondisi tersebut diduga dapat mempengaruhi tingkat WTP. Menurut Derkzen et al. (2017), perbedaan dalam WTP dipengaruhi oleh faktor sosial ekonomi, masyarakat dengan pendapatan yang lebih tinggi menunjukkan tingkat WTP yang lebih besar dibandingkan dengan yang pendapatannya lebih rendah. Jenis kontribusi dengan membentuk komunitas hijau dan aktif di masyarakat cukup mendapat perhatian responden, hal ini dapat menjadi potensi dalam meningkatkan partisipasi masyarakat pada kegiatankegiatan yang mendukung program pemerintah.

\section{Preferensi Mengenai Insfastruktur Hijau}

\section{Manfaat Insfrastruktur Hijau yang Ingin Diprioritaskan}

Menurut hasil persentase yang disajikan pada Tabel 3 terkait preferensi masyarakat mengenai manfaat infrastruktur hijau yang ingin diprioritaskan pada Zona 1, 2, dan 3 pilihan bermanfaat secara ekologis memiliki persentase tertinggi, sedangkan manfaat untuk berproduksi dan dapat dipanen memperoleh persentasi 
terendah pada Zona 1 dan 2. Pada Zona 3 persentase terendah diperoleh oleh manfaat dengan mengutamakan keindahan. Manfaat meningkatkan fungsi estetika yang diberikan infrastruktur hijau kurang mendapat perhatian dari masyarakat, hal ini sejalan dengan hasil analisis sebelumnya terkait persepsi responden terhadap manfaat penting yang dapat diberikan oleh infrastruktur hijau.

\section{Jenis Insfrastuktur yang Ingin Diprioritaskan}

Pada Zona 1 dan 2, jalur hijau kota memiliki persentase tertinggi untuk preferensi infrastruktur hijau pada skala kota untuk diprioritaskan pengembangannya, sedangkan nilai terendah pada Zona 1 diperoleh danau atau embung dan sungai. Pada wilayah 2 nilai terendah diperoleh danau atau embung. Berbeda pada Zona 3, persentase tertinggi diperoleh hutan kota atau kebun binatang, sedangkan presentasi terendah diperoleh taman kota dan lapangan rumpu atau alun-alun dengan nilai setara. Menurut hasil uji Chi-Square yang disajikan pada Tabel 3, perbedaan proporsi yang signifikan terjadi pada preferensi terhadap hutan kota pada Zona 2 dan $3(<0.05)$. Preferensi untuk pengembangan terhadap hutan kota atau kebun binatang yang cukup tinggi pada Zona 3 diduga karena kebun binatang terletak pada Zona tersebut. Manusia cenderung lebih perhatian dan familiar dengan dengan hal-hal yang ada di lingkungannya, sehingga mereka akan memiliki keinginan untuk memperbaiki lingkungan yang ada disekitarnya. Preferensi tertinggi ini merupakan gambaran lingkungan yang secara teoritis, disarankan untuk dikembangkan karena memiliki banyak nilai positif secara ekologis dan arsitektural.

Perbedaan signifikan juga terjadi pada preferensi terhadap jalur hijau kota pada Zona 1 dan 2 dibandingkan dengan Zona $3(<0.05)$. Tingginya preferensi masyarakat pada Zona 1 dan 2 untuk memprioritaskan pengembangan jalur hijau diduga karena mayoritas responden pada zona ini merupakan pelajar atau mahasiswa dan pekerja yang perlu melakukan aktifitas di luar rumah. Jalur hijau merupakan salah satu jenis infrastruktur hijau yang hampir setiap hari dapat dirasakan manfaatnya bagi masyarakat dibandingkan jenis infrastruktur hijau lainnya. Jalur hijau jalan berfungsi sebagai pengatur iklim mikro dan sebagai perlindungan bagi pejalan kaki dari hujan dan sengatan matahari. Jalur hijau jalan juga mampu mengurangi polusi dari kendaraan bermotor. Pohon yang berada di sekitar jalan raya mampu menyerap 9 kali lebih banyak polutan, dan mengubah gas berbahaya menjadi oksigen dan gas-gas alami lain yang berguna. Fungsi lainnya adalah, sebagai peredam kebisingan, pembentuk citra kota, juga untuk mengurangi kebutuhan infrastruktur saluran drainase (Ulum dan Ngindana, 2017).

\section{Jenis Insfrastuktur yang Ingin Diprioritaskan pada Skala Lingkungan}

Preferensi infrastruktur hijau pada skala lingkungan Zona 1 dan 2, taman lingkungan memiliki persentase tertinggi, sedangkan nilai terendah diperoleh green wall/vertical garden. Pada wilayah 2, presentasi terendah diperoleh oleh green roof. Pada wilayah 3, persentase tertinggi diperoleh pekarangan dan taman lingkungan dengan persentase seimbang, dan presentasi terendah diperoleh oleh green roof dan green wall/vertical garden dengan nilai yang sama juga. Besarnya perolehan nilai taman lingkungan sebagai preferensi infrastruktur hijau yang ingin diprioritaskan pada skala mikro, diduga karena taman lingkungan merupakan ruang terbuka dengan skala kecil yang dengan mudah dapat diakses oleh masyarakat setempat. Taman lingkungan menyediakan sarana rekreasi seperti permainan anak-anak, dan lapangan olahraga, juga dapat dimanfaatkan sebagai ruang komunal bagi masyarakat disekitarnya.

Menurut hasil uji Chi-Square, perbedaan proporsi yang signifikan terjadi pada preferensi terhadap Zona 1 dan 2 terkait preferensi terhadap pekarangan $(<0.05)$. Hal tersebut disebabkan oleh preferensi masyarakat pada Zona 1 terhadap pekarangan lebih tinggi dibandingkan pada Zona 2, sedangkan Zona 2 memiliki nilai preferensi yang lebih tinggi untuk green wall dibandingkan pada Zona 1. Meskipun demikian, green wall tetap memperoleh rata-rata nilai preferensi yang rendah bersamaan dengan green roof. Terlihat bahwa green wall dan green roof masih sangat kurang diminati oleh masyarakat, namun green wall dan green roof sesungguhnya memiliki banyak manfaat. Meskipun dalam skala kecil, sebuah komponen green wall dapat turut berkontribusi untuk menurunkan suhu lokal dan mengurangi dampak UHI (Alexandri dan Jones 2008). Namun, masyarakat masih relatif kurang familiar dan cenderung memiliki kekhawatiran mengenai pemeliharaan green wall/vertical garden (Derkzen et al. 2017).

\section{Jenis Vegetasi yang Ingin Diprioritaskan pada Infrastruktur Hijau}

Hasil penelitian menunjukan bahwa pohon dominan menjadi preferensi tertinggi sebagai vegetasi yang diinginkan untuk diperbanyak di jalur hijau kota di ketiga zona, dan sebagian responden memilih tanaman berbunga dan rumput. Nilai preferensi tertinggi terhadap pohon untuk jalur hijau jalan terjadi pada Zona 1 (96.7\%). Menurut penelitian, masyarakat di daerah miskin infrastruktur hijau lebih menyukai pohon dibandingkan semak. Masyarakat yang tinggal dekat dengan jalan-jalan yang hijau tidak membutuhkan infrastruktur hijau baru sedangkan mereka yang tinggal di jalan-jalan tanpa infrastruktur hijau membutuhkan lebih banyak tanaman hijau, terutama pohon.

Pohon juga menjadi preferensi tertinggi sebagai vegetasi yang diinginkan untuk diperbanyak di taman kota, tanaman berbunga memiliki persentase cukup tinggi, dan rumput pada urutan ketiga. Hal ini sejalan dengan penelitian yang dilakukan Harris et al. (2017), pohon menjadi komponen yang paling disukai dengan hasil presentasi tertinggi dibandingkan dengan rumput dan infrastruktur lainnya dalam beberapa studi kasus. Masyarakat diduga telah menyadari beragam manfaat yang dapat diberikan oleh pohon. Pohon perkotaan memberikan manfaat terukur untuk kualitas lingkungan perkotaan dan kualitas hidup perumahan. Pohon mampu mengurangi tekanan panas perkotaan, mengurangi limpasan hujan, banjir, tingkat kebisingan, dan kecepatan angin, serta mampu menghilangkan polutan udara. "Cooling effect" yang diberikan pohon di daerah perkotaan menjadi sangat penting terhadap dampak perubahan iklim (Gerstenberg \& Hofmann 2016).

\section{Perencanaan dan Pengelolaan Insfrastruktur Hijau yang Ingin Diprioritaskan}

Pada Zona 1, membebaskan kawasan yang memiliki peruntukan sebagai infrastruktur hijau menjadi preferensi tertinggi, sedangkan mengoptimalkan infrastruktur hijau 
yang ada memperoleh presentasi terendah. Pada Zona 2, melakukan pengembangan berdasarkan kebutuhan prioritas menjadi preferensi tertinggi, sedangkan membuat kebijakan memperoleh presentasi terendah. Pada Zona 3 membebaskan kawasan dan mengembangkan infrastruktur hijau berdasarkan area prioritas memiliki persentase tertinggi, kemudian membuat kebijakan tegas memperoleh presentasi terendah.

Berdasarkan hasil uji Chi-Square yang disajikan Tabel 3, perbedaan proporsi signifikan terjadi pada preferensi terhadap jenis perencanaan dengan mengoptimalkan infrastruktur hijau yang sudah ada pada Zona 1 dan 2 $(<0.05)$. Pada Zona 1, pilihan tersebut lebih rendah dibandingkan Zona 2. Preferensi responden pada Zona 2, cenderung lebih tinggi terhadap pilihan perencanaan strategis, seperti mengoptimalkan infrastruktur hijau yang ada dan mengembangkan infrastruktur hijau berdasarkan area prioritas tertentu. Responden Zona 1 lebih banyak memilih jenis perencanaan dengan membebaskan kawasan yang memiliki peruntukan sebagai infrastruktur hijau, hal tersebut diduga karena responden menginginkan peningkatan kuantitas dari infrastruktur hijau yang ada pada wilayahnya.

\section{Rekomendasi Konsep Pengembangan Untuk Meningkatkan Kualitas Insfrastruktur Hijau Kota Yogyakarta}

Berdasarkan hasil pengelompokan zona prioritas dan hasil dari preferensi masyarakat, kemudian diperoleh rekomendasi arahan pengembangan infrastruktur hijau (Tabel 4). Setelah ditentukan jenis infrastruktur hijau yang akan dikembangkan, kemudian disusun rekomendasi infrastruktur hijau yang efektif dalam upaya memperbaiki iklim mikro pada masing-masing zona prioritas. Pada Zona 1 dan Zona 2 di skala kota akan diprioritaskan pengembangan jalur hijau kota dengan mengutamakan fungsi ekologis sebagai pengatur iklim mikro, memperbaiki kualitas udara, dan mengurangi polusi, sedangkan pada Zona 3 responden menginginkan pengembangan kebun binatan atau hutan kota. Pada Zona 1 dan 2 pada skala lingkungan akan diprioritaskan pengembangan taman lingkungan dengan mengutamakan fungsi ekologis, sedangkan pada Zona 3 akan dikembangkan taman lingkungan dan pekarangan.

Pohon merupakan jenis vegetasi yang ingin diprioritaskan untuk ditambah kuantitasnya pada elemen-elemen infrastruktur hijau kota oleh masyarakat. Pohon sebagai unsur penting dalam RTH kota memiliki fungsi ekologis dalam memperbaiki kualitas lingkungan, antara lain dalam menyimpan dan menjerap karbon, mereduksi laju limpasan permukaan, menyerap radiasi matahari dan mereduksi penggunaan energi di lingkungan perkotaan (Nowak et al. 1998 dalam Fatimah et al. 2013). Kanopi pohon adalah solusi optimal untuk memberi naungan pada ruang pedestrian. Kanopi pohon dan elemen lain dari ruang hijau perkotaan menciptakan pendinginan bagi iklim mikro dari hasil evapotranspiratif (Rosenzweig et al. 2006, Madureira \& Andresen 2014).

Jenis pohon yang akan diprioritaskan merupakan tanaman khas atau identitas Kota Yogyakarta seperti sawo kecik (Manilkara kauki), sawo bludru (Chrysopyllum cainito), kepel (Stelechocarpus burahol), melinjo (Gnetum gnemon), gayam (Inocarpus fagifer), asam jawa (Tamarindus indica), dan beringin (Ficus benjamina). Sawo kecik dapat berkontribusi untuk membantu penyerapan $\mathrm{CO}_{2}$ meskipun kapasitasnya tidak terlalu tinggi, selain itu tanaman ini juga berfungsi sebagai pohon peneduh. Sawo bludru atau sawo ijo, selain berfungsi sebagai tanaman hias diperkotaan juga dapat berfungsi sebagai pohon peneduh. Pohon kepel merupakan salah satu jenis tanaman yang berpotensi tinggi untuk menyerap dan menjerap timbal dan debu di perkotaan. Pohon melinjo merupakan tanaman lanskap yang berpotensi tinggi dalam menyerap polutan gas $\mathrm{NO}_{2}$. Pohon gayam dapat berfungsi sebagai pohon peneduh dan penahan erosi, pohon gayam mampu menyerap polutan udara seperti debu yang lebih banyak karena tekstur daunnya tebal, lebar serta rimbun. Pohon asam jawa berfungsi sebagai penahan dan penyaring gas dan partikel padat dari udara,

Tabel 4. Rekomendasi Arahan Pengembangan Infrastruktur Hijau Kota Yogyakarta

\begin{tabular}{|c|c|}
\hline $\begin{array}{l}\text { Kelompok } \\
\text { area prioritas }\end{array}$ & Rekomendasi pengembangan \\
\hline Zona 1 & $\begin{array}{l}\text { Membangun infrastruktur hijau yang bermanfaat secara ekologis (sebagai pengatur iklim mikro, } \\
\text { memperbaiki kualitas udara, dan mengurangi polusi). } \\
\text { Pada skala kota memprioritaskan jalur hijau kota untuk dikembangkan. } \\
\text { Pada skala lingkungan memprioritaskan taman lingkungan untuk dikembangkan. } \\
\text { Memperbanyak pohon peneduh pada jalur hijau dan taman kota. } \\
\text { Melakukan penertiban dengan membebaskan kawasan yang memiliki peruntukan sebagai } \\
\text { infrastruktur hijau. }\end{array}$ \\
\hline Zona 2 & $\begin{array}{l}\text { Membangun infrastruktur hijau yang bermanfaat secara ekologis (sebagai pengatur iklim mikro, } \\
\text { memperbaiki kualitas udara, dan mengurangi polusi). } \\
\text { Pada skala kota memprioritaskan jalur hijau kota untuk dikembangkan. } \\
\text { Pada skala lingkungan memprioritaskan taman lingkungan untuk dikembangkan. } \\
\text { Memperbanyak pohon peneduh pada jalur hijau dan taman kota. } \\
\text { Mengembangkan infrastruktur hijau berdasarkan area prioritas. }\end{array}$ \\
\hline Zona 3 & $\begin{array}{l}\text { Membangun infrastruktur hijau yang bermanfaat secara ekologis (sebagai pengatur iklim mikro, } \\
\text { memperbaiki kualitas udara, dan mengurangi polusi). } \\
\text { Pada skala kota memprioritaskan hutan kota/ kebun binatang untuk dikembangkan. } \\
\text { Pada skala lingkungan memprioritaskan taman lingkungan dan pekarangan untuk } \\
\text { dikembangkan. } \\
\text { Memperbanyak pohon peneduh pada jalur hijau dan taman kota. } \\
\text { Melakukan penertiban dengan membebaskan kawasan yang memiliki peruntukan sebagai } \\
\text { infrastruktur hijau dan mengembangkan infrastruktur hijau berdasarkan area prioritas. }\end{array}$ \\
\hline
\end{tabular}


serta sebagai penghasil oksigen dan sering juga digunakan sebagai tanaman peneduh. Pohon beringin merupakan salah satu tanaman yang mempunyai kemampuan tinggi sebagai penyerap $\mathrm{CO}_{2}$ dan sering digunakan sebagai peneduh.

\section{Jalur Hijau Jalan}

Konsep pengembangan yang akan digunakan untuk jalur hijau jalan menggunakan konsep green street dengan memaksimalkan keberadaan pohon jalan. Green street dapat diterapkan di badan jalan baik di trotoar, pedestrian, atau jalur hijau. Desain green street dapat menggabung berbagai elemen desain seperti pohon jalan, trotoar permeabel (tidak kedap air), bioretensi, dan sengkedan (Prastiwi 2017).

Permukaan trotoar juga menggunakan material-material yang permeabel untuk meningkatkan kapasitas infiltrasi dan mengurangi suhu permukaan. Street trees dapat mengurangi efek UHI, mengurangi limpasan air hujan, meningkatkan estetika perkotaan, dan meningkatkan kualitas udara (US EPA 2008). Menurut Starke et al. (2010), peluang penguapan air dari trotoar permeabel memiliki potensi untuk mengurangi suhu permukaan dibandingkan dengan permukaan kedap air sejenis dan dapat mengurangi jumlah panas yang disimpan sepanjang hari yang kemudian dilepaskan saat malam hari. Maka dari itu trotoar permeabel memiliki potensi untuk mengurangi dampak UHI.

\section{Hutan Kota atau Kebun Binatang}

Kebun raya, hutan raya dan kebun binatang dapat dimasukkan ke dalam salah satu bentuk hutan kota. Keberadaan hutan kota merupakan faktor penting yang berpengaruh terhadap keberlanjutan kondisi ekologi dan sosial di lingkungan perkotaan. Hutan kota yang didominasi oleh banyak jenis pohon mampu mereduksi polutan lebih banyak dari pada hutan kota yang memiliki dominansi vegetasi rendah (Yang et al. 2005 dalam Alfian 2015). Pemilihan vegetasi yang sesuai merupakan tindakan yang cukup penting karena jenis vegetasi yang mendominasi hutan kota dapat berpengaruh terhadap suhu dan kelembaban. Meningkatkan dominasi vegetasi yang sesuai, dan meningkatkan keragaman vegetasi dapat meningkatkan kenyamanan termal sekitar hutan kota (Alfian 2015). Kebun Binatang gembira loka merupakan jenis hutan kota yang memiliki pola bentuk menyebar, sehingga hutan kota ini sangat berpotensi mengurangi suhu disekitarnya, dibandingkan dengan pola bentuk hutan kota yang bergerombol atau bentuk menjalur.

\section{Taman Lingkungan}

Taman lingkungan memiliki fungsi ekologis dan estetis. Fungsi ekologis meliputi menciptakan iklim mikro yang nyaman, penyerapan air hujan, dan memelihara ekosistem tertentu. Pekarangan memiliki fungsi ekologis yang sangat penting. Pola desain taman lingkungan sebaiknya menggunakan pola tertutup atau dapat juga dengan pola desain terbuka dengan dominasi rumput pada tutupan tanahnya. Pola tersebut merupakan bentuk taman lingkungan yang mampu menurunkan suhu udara taman dan sekitarnya. Pengaruh peningkatan penutupan vegetasi akan memberikan pengaruh secara signifikan terhadap penurunan suhu udara taman dan sekitarnya apabila pada taman tersebut memiliki vegtasi yang rapat dan padat, sedangkan pada taman dengan minim penutupan vegetasi tidak memberikan pengaruh terhadap penurunan suhu udara (Harti 2004).

\section{Pekarangan}

Pekarangan yang ekologis terdiri dari keragaman strata vegetasi. Menurut Arifin (1998), keragaman strata dibagi kedalam lima strata ketinggian. Strata I merupakan tanaman dengan ketinggian yang kurang dari $1 \mathrm{~m}$ seperti rumput dan herba, strata II merupakan tanaman dengan ketinggian antara 1-2 m seperti semak, strata III adalah tanaman yang memiliki ketinggian antara 2-5 m seperti perdu dan pohon kecil, tanaman dengan strata IV memiliki ketinggian 5-10 m seperti pohon sedang, dan pohon tinggi dengan ketinggian di atas $10 \mathrm{~m}$ dikelompokan dalam strata $\mathrm{V}$.

Menurut Arifin et al. (1997), ukuran pekarangan diklasifikasikan menjadi tiga kategori, yaitu: $0 \mathrm{~m}^{2}$ hingga $200 \mathrm{~m}^{2}$ (kecil), $200 \mathrm{~m}^{2}$ hingga $500 \mathrm{~m}^{2}$ (sedang), dan lebih dari $500 \mathrm{~m}^{2}$ (besar). Pada Zona 3 ditemukan mayoritas ukuran pekarangan masuk dalam kategori kecil dan sedang, bervariasi antara $30 \mathrm{~m}^{2}-384 \mathrm{~m}^{2}$. Menurut Ilmy (2015), rekomendasi vegetasi untuk pekarangan berukuran kecil dengan memenuhi keragaman strata ketinggian misalnya, sukun, kelapa, nangka, mangga, rambutan, pisang, jambu biji, jeruk nipis, singkong, hanjuang, puring, talas, lidah mertua, kucai, dan pandan. Rekomendasi vegetasi untuk pekarangan ukuran sedang misalnya, nangka, mangga, salam,rambutan pisang jambu biji, jeruk nipis, singkong, jarak, puring, lidah mertua, kucai, dieffenbachia, pandan, teh-tehan, cabai rawit, kangkung darat, dan terong.

\section{SIMPULAN}

Terdapat perbedaan persepsi masyarakat pada zona prioritas yang berbeda, namun tidak terdapat banyak perbedaan pada preferensi masyarakat terhadap infrastruktur hijau. Mayoritas responden telah memiliki kesadaran mengenai isu terkait perubahan iklim dan paham cara memitigasi masalah tersebut. Sebanyak $62.2 \%$ responden menyatakan bahwa mereka mengetahui apa yang dimaksud dengan infrastruktur hijau, namun hanya sebanyak $50 \%$ responden yang menyatakan mampu menyebutkan contoh dari elemen infrastruktur hijau dengan tepat. Hal ini menunjukkan bahwa baru sebagian masyarakat Kota Yogyakarta yang paham mengenai istilah infrastruktur hijau. Preferensi masyarakat masih sangat rendah terhadap beberapa jenis infrastruktur hijau seperti green roof, vertical garden, dan RTB seperti embung dan sungai. Padahal jenis-jenis infrastruktur hijau tersebut memiliki potensi untuk dikembangkan di wilayah perkotaan padat seperti Kota Yogyakarta.

Untuk rekomendasi konsep pengembangan infrastruktur hijau yang efektif dalam upaya memperbaiki iklim mikro berdasarkan preferensi masyarakat pada Zona 1 dan 2 dalam skala kota akan diprioritaskan pengembangan jalur hijau kota dengan mengutamakan fungsi ekologis, sedangkan pada Zona 3 responden menginginkan pengembangan kebun binatang. Pada Zona 1 dan 2 pada skala lingkungan akan diprioritaskan pengembangan taman lingkungan dengan mengutamakan fungsi ekologis, sedangkan pada Zona 3 akan dikembangkan taman lingkungan dan pekarangan ekologis. Fungsi ekologis yang dimaksud dalam pengembangan masih terkait ruang lingkup dalam upaya memperbaiki iklim 
mikro. Kesadaran akan masalah lingkungan ini dapat berfungsi sebagai alat untuk beradaptasi dan memitigasi lingkungan kota terhadap perubahan iklim untuk meningkatkan strategi perencanaan kota.

\section{DAFTAR PUSTAKA}

Alexandri, E., Jones, P. 2008. Temperature decreases in a urban canyon due to green walls and green roofs in diverse climates. Building and Env. 43:480-493.

Alfian, R. 2015. Pengaruh Bentuk Hutan Kota Terhadap Kenyamanan Termal di Sekitar Hutan Kota [skripsi]. Bogor (ID): Institut Pertanian Bogor.

Arifin, H.S., Sakamoto, K., Chiba, K. 1998. Effect of urbanization on the performance of the home garden in West Java, Indonesia. Japanese J of Tropical Agric. 61(4):325-333.

Barau, A.S. 2015. Perceptions and contributions of households towards sustainable urban green infrastructure in Malaysia. Habitat Int. 47(2015):285-297.

Brown, R., Vanos, J.K., Kenny, N.A., Lenzholzer, S. 2015. Designing urban parks that ameliorate the effects of climate change. Landscape and Urban Planning, 138, 118-131.

Byrne, J., Yang, J. 2009. Can urban greenspace combat climate change? Towards a subtropical cities research agenda. Australian Planner, 46, 36-43.

Chan, K.M.A., Satterfield, T., Goldstein, J. 2012. Rethinking ecosystem services to better address and navigate cultural values. Ecol. Econ. 74, 8-18.

Countryside Agency. 2006. Countryside in and Around Towns: The Green Infrastructure of Yorkshire and the Humber. Leeds (UK): Countryside Agency.

Demuzere, M., Orru, K., Heidrich, O., Olazabal, E., Geneletti, D., Orru, H. 2014. Mitigating and adapting to climate change: multi-functional and multi-scale assessment of green urban infrastructure. Journal of Environmental Management, 146, 107-115.

Derkzen, M.L., Teeffelen, A.J., Verburg, P.H. 2017. Green infrastructure for urban climate adaptation: How do residents' views on climate impacts and green infrastructure shape adaptation preferences? Landscape and Urban Planning, 157, 106-130.

Fatimah, I.S., Sinukaban, N., Munandar, A., Kholil. 2013. Valuasi manfaat ekologis ruang terbuka hijau (RTH) di Kota Bogor dengan aplikasi Citygreen 5.4. JPSAL. 3(1): 31-38.

Gao, J., Sun, Y., Liu, Q., Zhou, M., Lu, Y., \& Li, L. 2015. Impact of extreme high temperature on mortality and regional level definition of heat wave: a multi-city study in China. Science of the Total Environment, 505, 535544.

Gerstenberg, T., Hofmann, M. 2016. Perception and preference of trees: A psychological contribution to tree species selection in urban areas. Urban Forestry \& Urban Greening. 15(2016):103-111

Guntara, I. 2015. Pemanfaatan Citra Landsat 8 untuk Mengestimasi Suhu Permukaan Lahan (Land Surface Temperature) di Kabupaten Bantul Menggunakan Split
Window Algorithm [skripsi]. Yogyakarta (ID): Universitas Gajah Mada.

Harris, V., Kendal, D., Hahs, A.K., Threlfall, C.G. 2017. Green space context and vegetation complexity shape peoples preferences for urban public parks $\mathcal{E}$ residential gardens. Landscape Rsch 1-13.

Harti, C.I. 2004. Pengaruh Taman Lingkungan Terhadap Suhu Udara Sekitarnya. [Skripsi]. Bogor (ID): Institut Pertanian Bogor.

Ilmy, F. 2015. Model Pekarangan Ekologis di Hulu DAS Kali Bekasi, Kabupaten Bogor. [Skripsi]. Bogor (ID): Institut Pertanian Bogor.

Kati, V., Jari, N. 2016. Bottom-up thinking - Identifying sociocultural values of ecosystem services in local blue-green infrastructure planning in Helsinki, Finland. Land Use Policy. 50:537-547

Madureira, H., Andresen, T. 2014. Planning for multifunctional urban green infrastructures: Promises and challenges. Urban Design International, 19, 38-49.

Nurisjah, S. 2005. Penilaian Masyarakat Terhadap Ruang Terbuka Hijau (RTH) Wilayah Perkotaan: Kasus Kotamadya Bogor [disertasi]. Bogor (ID): Institut Pertanian Bogor.

Prastiwi, I. 2017. Desain Konseptual Green Street Di Kota Bogor Sebagai Sarana Penanggulangan Banjir Hijau [Tesis]. Bogor (ID): Institut Pertanian Bogor.

Pratiwi, R.D. 2019. Konsep Pengembangan Infrastruktur Hijau Berbasis Land Surface Temperature di Kota Yogyakarta. [tesis]. Bogor (ID): Institut Pertanian Bogor.

Rosenzweig, C., Solecki, W., Parshall, L., Gaffin, S., Lynn, B., Goldberg, R. 2006. Mitigating New York City's heat island with urban forestry, living roofs, and light surfaces. Proceedings of the sixth symposium on the urban env Atlanta.

Semenza, J.C., Hall, D.E., Wilson, D.J., Bontempo, B.D., Sailor, D.J., George, L.A. 2008. Public Perception of Climate Change Voluntary Mitigation and Barriers to Behavior Change. American Journal of Preventive Medicine. 35(5), 479-487.

Starke, P, Gobel P, Coldeway, W.G. 2010. Urban evaporation rates for water permeabel peavments. Water Science and Tech. 62:1161-1169.

Tzoulas, K., Korpela, K., Venn, S., Yli-Pelkonen, V., Kazmierczak, A., Niemela, J., James, P. 2007. Promoting ecosystem and human health in urban areas using Green Infrastructure: A literature review. Landscape and Urban Planning, 81, 167-178.

Ulum, M.C., Ngindana, R. 2017. Environmental Governance: Isu, Kebijakan, dan Tata Kelola Lingkungan Hidup. Malang (ID): UB Press.

[US EPA] United States Environmental Protection Agency. 2008. EPA's Report on the Environment. Washington DC (US): National Center for Environmental Assessment. 